\title{
Digital color correlation for the recognition of Vibrio cholerae 01 in laboratory and environmental samples
}

\author{
Correlación digital del color para el reconocimiento de Vibrio cholerae 01 en \\ muestras ambientales y de laboratorio
}

\section{Rosa R. Mouriño-Pérez ${ }^{1}$, Josué Alvarez-Borrego ${ }^{2}$ and Cristián Gallardo-Escárate ${ }^{2,3}$}

\author{
${ }^{1}$ División de Biología Experimental y Aplicada, Departamento de Microbiología \\ ${ }^{2}$ Dirección de Física Aplicada, Departamento de Óptica, Centro de investigación Científica y Educación Superior de Ensenada. \\ Km. 107 Carretera Tijuana-Ensenada, Ensenada B.C., México. C.P. 22860 \\ ${ }^{3}$ Universidad Católica del Norte, Departamento de Biología Marina, Citogenética y Análisis de Imágenes, \\ Larrondo 1281, Casilla 117, Coquimbo-Chile \\ josue@cicese.mx
}

\begin{abstract}
Resumen.- En general, el conteo directo refleja más la abundancia microbiológica que el conteo de placas. Se han desarrollado técnicas microbiológicas para reconocer y contar microorganismos en sistemas naturales pero han tenido problemas con la confiabilidad de sus resultados. Frecuentemente, métodos distintos dan diferentes resultados para la enumeración de un organismo específico. Para la examinación directa al microscopio de bacterias, los sistemas digitales automatizados representan un posible avance en la identificación y conteo, eliminando una predisposición del observador y reduciendo costos y tiempo de análisis. En este trabajo se desarrolló un programa computacional para evaluar la utilidad de sistemas ópticos coherentes para el reconocimiento de Vibrio cholerae 01, mediante correlación de color en cultivos de laboratorio y de muestras ambientales teñidas con anticuerpos monoclonales fluorescentes. De muestras de laboratorio probamos 94 muestras positivas y 115 negativas y 33 muestras positivas y 34 negativas de muestras ambientales y 613 muestras positivas y 546 negativas de muestras de mesocosmos. En muestras de laboratorio se llevó a cabo una correcta identificación, un conteo de células y una discriminación a un $100 \%$. La sensibilidad del sistema digital en muestras ambientales como en muestras análogas al ambiente varió de $91 \%$ a $94 \%$ y tuvo un $99,5 \%$ de discriminación entre otras bacterias o partículas. Basados en los valores absolutos de correlación en los componentes rojo, verde y azul de las imágenes policromáticas de $V$. cholerae 01 (canales RGB), el algorítmo para contar e identificar correlacionó bien con los picos en la salida del canal verde y no hubo picos de salida en los canales rojo y azul. El criterio de discriminación correlacionó bien con los picos presentes en los canales rojo y azul. Concluímos que el sistema digital de correlación de color para identificar y contar $V$. cholerae 01 de muestras ambientales y de laboratorio es una herramienta útil con alta confiabilidad.
\end{abstract}

Palabras clave : Identificación, sistemas digitales, bacteria

\begin{abstract}
In general, direct counts are more reflective of microbial abundance than plate counts. Microbiological techniques developed to recognize and count microorganisms in natural systems have had problems with reliability. Different methods frequently give different results for the enumeration of a specific organism. For direct microscopic examination of bacteria, automated digital systems represent a possible improvement in the identification and counting of microorganisms, eliminating observer bias, reducing costs and analysis time. A computational program was developed to evaluate the utility of coherent digital systems with color correlation for the recognition of Vibrio cholerae 01 in laboratory cultures and environmental samples stained with fluorescent monoclonal antibody. We tested 94 positive and 115 negative laboratory samples and, 33 positive and 34 negative environmental samples and 613 positive and 546 negative mesocosms samples. Correct identifications, cell counts and discrimination were possible in $100 \%$ of the laboratory samples. The sensitivity of the system with environmental and environmental-like samples varied between $91 \%$ to $94 \%$ and $99.5 \%$ discrimination between other bacteria or particles. Based on the absolute correlation values in red, green and blue components of the polychromatic $V$. cholerae 01 images (RGB channels), the algorithm to count and identify it correlated well with the peaks in the green channel output and were absent in both the red and blue channels. The discrimination criterion correlated well with the peaks present in the red and blue channels. We conclude that digital color correlation system is an useful and highly reliable tool to identify and count $V$. cholerae 01 in laboratory and environmental samples.
\end{abstract}

Key words: Identification, digital systems, bacteria 


\section{Introduction}

Optical-digital automated systems are new methods that improve screening for the presence and quantity of some microorganisms in their natural environment. Automatic systems eliminate the observer bias, reduce analysis time and relieve researchers from the tedious task of large amounts of microscopic observation.

The introduction of techniques such as digital processing of images taken directly from the microscope for the surveillance and analysis of virulent microorganisms could significantly reduce the time required to obtain data.

Many successful optical-digital correlation methods for image processing have been developed based on the shape of the organism of interest (Pech-Pacheco \& Alvarez-Borrego 1998). These methods are based on developing filters that include information on the shape of the organism of interest from the spatial field transformed to the frequencies field (Fourier transform). The filter is correlated with images of samples, which could have the organism under study in order to identify its presence. Several kinds of filters have been developed with different techniques in order to recognize several objects, including bioparticles (Van der Lugt 1964, Zavala-Hamz \& Alvarez-Borrego 1997, Pech-Pacheco \& Alvarez-Borrego 1998).

However, bacterial shape does not give enough information to develop a filter for specific recognition. Different bacterial shapes are shared among many species. Additional information is needed to recognize specific species and strains. Marking cells with specific colors is one option. In Vibrio cholerae 01 it is possible to label the bacteria with monoclonal antibodies associated with fluorescein that possess a bright green fluorescence in order to discriminate them from other bacteria.

Direct fluorescent antibodies (DFA) is itself a fast and highly specific staining method that allows for the rapid and reliable identification of $V$. cholerae 01 in environmental samples (Hasan et al. 1993, 1994, and 1995). However, samples processed with DFA currently have to be evaluated by an observer, who has to develop skill and experience to recognize the organism in complex assemblages of particles. Reading slides causes fatigue as well as unreliable data, and it is timeconsuming. The observer's capacity is limited and observation reliability decreases as the number of samples increase.

We propose an automated technique for bacterial identification and quantification based on color and shape. Combining color information with shape has previously resulted in a high level of target recognition (Bradiqué, 1987, Millán et al. 1989, 1991, 1992, Ferreira et al. 1992, Millán et al. 1995). Since the color observed depends on the wavelength of illumination, a polychromatic object can be decomposed using monochromatic channels. The most common decomposition is in red, green and blue (RGB) light, as done for example by color monitors for computers and televisions. The sum of the information in each channel gives the complete color image of the object. In this report we present data on decomposing color images of stained $V$. cholerae cells (culturable and non-culturable stages) and correlating each image channel with $V$. cholerae abundance.

We chose the cholera problem regards its importance in public health, its relation with global climate changes and the need for long-term environmental screening of $V$. cholerae in coastal zones to generate information about its behavior as a pathogen, its vectors, reservoirs and hosts (Singleton et al. 1982a, 1982b, Tamplin \& Colwell 1986, Tamplin et al. 1990, Colwell \& Huq 1994, Huq \& Colwell 1995).

\section{Material and methods}

\section{Strain and inoculum preparation}

V. cholerae 01 Inaba Eltor (FMV087145) was kindly provided by Medicine School of UNAM for microcosm experiments and $V$. cholerae $01 \mathrm{~N} 16961$ was kindly provided by J. Mekalanos, Harvard University for mesocosms. Before experiments, $\mathrm{T}_{1} \mathrm{~N}_{1}$ agar plates (1\% tryptone, $1 \%$ sodium chloride, $1.5 \%$ agar) were inoculated with $V$. cholerae N16961 and incubated overnight at $37^{\circ} \mathrm{C}$. A loopful of the resulting growth was resuspended in $150 \mathrm{ml}$ of seawater amended with $0.1 \%$ tryptone and incubated at room temperature (23 \pm $1^{\circ} \mathrm{C}$ ) overnight. Cells were then harvested by centrifugation (3100 x $\mathrm{g}, 10 \mathrm{~min}, \mathrm{rt})$, the supernatant aspirated, and the remaining pellet resuspended in 0.2 $\mu \mathrm{m}$ filter-sterilized, autoclaved phosphate-buffered saline (PBS; pH 7.4). This washing process was repeated 5 times to prevent the carry over of media nutrients. Finally, the pellet was resuspended in PBS 
for subsequent inoculation of microcosms and or mesocosms.

\section{Experimental design}

We performed three different experiments to evaluate the digital recognition of $V$. cholera 01 under different conditions.

\section{First experiment}

Microcosm experiments were performed using an estuarine condition with a low nutrient concentration including different stages and morphologies of $V$. cholerae 01, in order to develop culturable and nonculturable stages.

Two Pyrex flasks (250 ml) with lid were rinsed six times with particle free, distilled, deionized water. The flasks were filled with $160 \mathrm{ml}$ of $20 \%$ seawater simulation (13.67 g NaCl, $2.29 \mathrm{~g} \mathrm{Na}_{2} \mathrm{SO}_{4}, 0.38 \mathrm{~g} \mathrm{KCl}$, 0.112 g NaHCO $3,0.015$ g $_{3} \mathrm{BO}_{3}, 0.0016$ g NaF, 0.023 g $\mathrm{MgCl}_{2} 6 \mathrm{H}_{2} \mathrm{O}$, $0.5 \mathrm{~g}$ yeast extract in $1000 \mathrm{~mL}$ of distilled and deionized water) and $0.5 \%$ of peptone $(\mathrm{pH}$ $7.4)$ and they were sterilized by autoclaving $\left(121^{\circ} \mathrm{C}, 20\right.$ $\min )$.

Two microcosms were inoculated with $V$. cholerae 01 Inaba Eltor (FMV087145) and incubated at $25^{\circ} \mathrm{C}$ for 90 days.

Culturability was tested every day. In addition, a 1 $\mathrm{mL}$ sample of the microcosm was taken and stabilized with 3\% formalin for subsequent Direct Immunofluorescence Antibody (DFA) test.

For negative controls, we used laboratory samples $V$. cholerae 01 free provided in the DFA kit that contains $10^{7}$ formalin-stabilized cells of $V$. cholerae non- 01 .

\section{Second experiment}

Positives and negative environmental samples were obtained from the collection of the Biotechnology Department at CICESE and processed for DFA. These samples were collected in the Tamiagua Lagoon in the coast of the Gulf of Mexico by dragging a net of 212$\mu \mathrm{m}$ pore size mesh for $30 \mathrm{~min}$ at 0.5 to $1.0 \mathrm{~m}$ depth. All the samples were tested by polymerase chain reaction (PCR) to corroborated the presence of $V$. cholerae 01 .

\section{Third experiment}

Mesocosm experiment was performed, placing $60 \mathrm{~L}$ of seawater in a 200-L tank and inoculating it with $V$. cholerae $01 \mathrm{~N} 16961$. It was incubated at room temperature. After four days 6 samples were taken and fixed with $2 \%$ formaldehyde. Samples were processed with DFA as well as sea water samples $V$. cholerae 01 free. A blind observation of both kinds of samples was performed by a person with experience in digital recognition. After the automated recognition the same scenes were evaluated by an expert in $V$. cholerae DFA stained samples and both results were compared.

\section{Colony forming units (CFU)}

$\mathrm{T}_{1} \mathrm{~N}_{1}$ agar plates were spread with $0.1 \mathrm{~mL}$ of sample dilutions ranging from $10^{0}$ to $10^{-5}$. Colonies were counted after incubation for $12 \mathrm{~h}$ at $37^{\circ} \mathrm{C}$ in the dark.

\section{DFA technique}

A $5 \mu \mathrm{L}$ drop of each day sample was placed into an eight-well slide, as well as $5 \mu \mathrm{L}$ of a positive and negative control. Each slide was dried at $37^{\circ} \mathrm{C}$ and fixed with $100 \%$ methanol. The lyophilized MAb-FITC conjugate was reconstituted with $1 \mathrm{~mL}$ of distilled deionized water, from which $5 \mu \mathrm{L}$ were added to each well. The slides were incubated in a humidified dark chamber at $37^{\circ} \mathrm{C}$ for 30 minutes, after which they were washed with phosphate buffer saline (PBS). The drying was performed by gently absorbing the moisture on the slides with a paper towel. The slides were then mounted with one drop of glycerol mounting medium. An Axiovert 100 epifluorescence microscope (Carl Zeiss, Inc. New York, N.Y.), with an Hbo50W high-pressure mercury lamp was employed to observe the slides. A 450-490 nm band-pass exciter filter (25-mm diameter, Carl Zeiss) was used for epifluorescence (Hasan et al. 1993, Hasan et al. 1994, 1995, Huq \& Colwell 1995).

For mesocosm, aliquots of 1-2 mL were filtered onto $0.2-\mu \mathrm{m}$-pore size black polycarbonate filters (Poretics) and processed as above. A motorized Leica epifluorescence microscope model DM RXA2 was used to observe samples.

Samples were observed immediately or stored at $-20^{\circ} \mathrm{C}$ and observed within 1 to 2 days by epifluorescence microscopy. 


\section{Recording fluorescent $V$. cholerae 01 images}

We recorded scenes from: a) microcosms with $V$. cholerae $01 \mathrm{~b}$ ) negative control of inmunofluorescence kit, c) environmental samples with $V$. cholerae 01 and d) environmental samples without $V$. cholerae 01 , in order to have positive and negative laboratory and seawater sample images. For the first and second experiments images were recorded with a color CCD camera EDC-1000E with a pixel size of $7.4 \mu \mathrm{m}$ and 7.4 $\mu \mathrm{m}$, and spatial resolution of $652(\mathrm{H})^{\prime} 494(\mathrm{~V})$ pixels. In order to improve and automate the processes of image recording and decrease time in the third experiment we use a motorized microscope. We recorded 2025 X 1526 pixels high resolution images with a CCD (DC300 Leica, pixel size 3.45 X $3.45 \mu \mathrm{m}$ ) and split in 256 X 256 pixels images. Both processes were automated.

Each scene was stored as a bitmap file with a CCD program and split channels (RGB) and we defined the function $f(x, y)$ for every pixel of coordinates $x$ and $y$ on the image as part of the digital program before the correlation.

\section{Multichannel correlation for polychromatic objects}

A numerical simulation was performed in order to correlate positive and negative laboratory and environmental images with Phase-only filters (POF). In the input plane, we placed all kinds of problem images. The input information is defined as a function

$$
f_{\lambda}\left(x_{1}, y_{1}\right) \text {. }
$$

It depends on beam wavelength illumination; then, for RGB channels

$$
f_{\lambda i}\left(x_{1}, y_{1}\right) . \quad i=\mathrm{R}, \mathrm{G}, \mathrm{B}
$$

Optically, those functions are obtained by successive illumination of the object with three different wavelengths $\lambda_{R}, \lambda_{G}$, and $\lambda_{B}$, and digitally splitting a polychromatic image in RGB channels.

In each channel, the input image $f_{\lambda_{\mathrm{i}}}\left(x_{1}, y_{1}\right)$ is correlated with a filter signal

$$
g_{\lambda \mathrm{i}}\left(x_{1}, y_{1}\right)
$$

which contains information of the target for each channel. Filters are obtained from representative individual images of $V$. cholerae 01 .
The Vander Lugt or classic filters are written as:

$$
G_{\lambda_{i}}(u, v)=\left|G_{\lambda_{i}}(u, v)\right| \exp \left(j \varphi_{\lambda_{i}}(u, v)\right) .
$$

where $G_{\lambda_{i}}$ is the Fourier transform of $g_{\lambda_{\mathrm{i}}}\left(x_{1}, y_{1}\right)$ in cartesian coordinates $u$ and $v$ in the Fourier plane and $\varphi_{\lambda_{i}}$ is the phase

$$
\begin{aligned}
& \text { For POF, }\left|G_{\lambda_{i}}(u, v)\right|=1 \text {, so } \\
& G_{\lambda_{i}}(u, v)=\exp \left(j \varphi_{\lambda_{i}}(u, v)\right) .
\end{aligned}
$$

Finally in the output plane, the correlation of the two signals $f_{\lambda_{i}}$ and $g_{\lambda_{i}}$ is given for each channel as

$$
C_{\lambda_{i}}\left(x_{3}, y_{3}\right)=F^{-1}\left(F_{\lambda_{i}}\left(x_{2}, y_{2}\right) \cdot G_{\lambda_{i}}^{*}\left(x_{2}, y_{2}\right)\right)
$$

where $\mathrm{FFT}^{-1}$ is the inverse Fourier transform and $G_{\lambda_{i}}^{*}$ is the complex conjugate of $G_{\lambda_{i}}$ and $F_{\lambda_{i}}\left(x_{2}, y_{2}\right)$ is the Fourier transform of $f_{\lambda_{\mathrm{i}}}\left(x_{1}, y_{1}\right)$.

If the correlation is positive we are going to find maximum correlation peaks in the same coordinates of the position of the object. In the $V$. cholerae 01 case, we considered a correct identification when we found a correlation peak in the green channel and no-peaks or very low peaks in the red and blue channels.

\section{Results and discussion}

Based in the first experiment, culturability of $V$. cholerae 01 was present until the $22^{\text {nd }}$ day of incubation. We developed a cluster analysis among individual images of the cholera bacillus representative of the majority of morphologic and size variations to calculate the linkage distance of those characteristics (data not shown). It was not possible to find a POF capable to differentiate between culturable and non-culturable stages, because the magnitude of the Euclidean distances did not show sufficient differences to develop filters for each stage.

We did not find enough morphological differences between the culturable and nonculturable stages to develop a filter to discriminate among the rod and cocoid shaped $V$. cholerae cells. Thus, during environmental monitoring for the presence of $V$. cholerae 01 the method presented here can be used to follow the presence of $V$. cholerae in a large number of samples in short period of time, but complementary 
tests should be performed on the positive samples to assess the physiological state of the cells.

Based on the cluster analysis, only two POF are needed to identify cholera bacteria with a minimal error in all cases.

\section{Identification of $\mathrm{V}$. cholerae 01}

With the digital color correlation system three different sets of images were evaluated: a) microcosms samples inoculated with $V$. cholerae 01 vs negative control samples, b) positive environmental samples vs negative environmental samples, and mesocosm samples inoculated with $V$. cholerae 01 vs seawater samples $V$. cholerae free.

For the first set of samples, we evaluated 94 256'256-pixels images of fluorescent $V$. cholerae and 115 negative scenes. Each image was split into RGB channels. We correlated images and POF in each channel. Table 1 presents absolute correlation values for all of the images. For microcosm images the mean of the absolute correlation values for the red and blue channels was higher for scenes without $V$. cholerae 01 ( $\mathrm{t}=23.31$ and 6.64 respectively, $P<0.01$ ). There were no differences in the green channel $(\mathrm{t}=0.32, P>0.01)$.

Table 1

Absolute correlation values in RGB channels of positive and negative $V$. cholerae 01 images

Valores absolutos de correlación en los canales RGB para imágenes positivas y negativas de V. cholerae 01

\begin{tabular}{|c|c|c|c|c|c|c|}
\hline Images & $\mathrm{n}$ & 壭 & 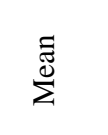 & $\begin{array}{l}\text { 95\% Confidence } \\
\text { interval }\end{array}$ & 㫯 & 营 \\
\hline $\begin{array}{l}\text { Vibrio cholerae } 01 \text { in microcosm } \\
\text { samples }\end{array}$ & 94 & $\begin{array}{l}R \\
G \\
B\end{array}$ & $\begin{array}{c}24.77 \\
265.20 \\
23.62\end{array}$ & $\begin{array}{c}21.89-27.65 \\
241.80-288.60 \\
20.75-26.50\end{array}$ & $\begin{array}{c}14.06 \\
114.25 \\
14.06\end{array}$ & $\begin{array}{c}1.45 \\
11.78 \\
1.45\end{array}$ \\
\hline $\begin{array}{l}\text { Vibrio cholerae } 01 \text { in environmental } \\
\text { samples }\end{array}$ & 33 & $\begin{array}{l}\mathrm{R} \\
\mathrm{G} \\
\mathrm{B}\end{array}$ & $\begin{array}{c}67.36 \\
180.50 \\
47.00\end{array}$ & $\begin{array}{c}53.31-81.40 \\
160.69-200.31 \\
35.97-58.03\end{array}$ & $\begin{array}{l}39.61 \\
55.86 \\
31.10\end{array}$ & $\begin{array}{l}6.89 \\
9.72 \\
5.41\end{array}$ \\
\hline Particles and Vibrio cholerae Non 01 & 15 & $\begin{array}{l}\mathrm{R} \\
\mathrm{G} \\
\mathrm{B}\end{array}$ & $\begin{array}{c}145.73 \\
272.34 \\
81.51\end{array}$ & $\begin{array}{c}127.90-163.55 \\
223.36-321.31 \\
53.95-109.07\end{array}$ & $\begin{array}{l}32.19 \\
88.44 \\
49.77\end{array}$ & $\begin{array}{c}8.31 \\
22.83 \\
12.85\end{array}$ \\
\hline $\begin{array}{l}\text { Environmental samples without } \\
\text { Vibrio cholerae } 01\end{array}$ & 34 & $\begin{array}{l}R \\
G \\
B\end{array}$ & $\begin{array}{c}76.23 \\
237.14 \\
82.86\end{array}$ & $\begin{array}{c}55.59-96.86 \\
211.73-262.56 \\
63.87-101.84\end{array}$ & $\begin{array}{l}59.13 \\
72.83 \\
54.41\end{array}$ & $\begin{array}{c}10.14 \\
12.49 \\
9.33\end{array}$ \\
\hline Total positive samples & 127 & $\begin{array}{l}\mathrm{R} \\
\mathrm{G} \\
\mathrm{B}\end{array}$ & $\begin{array}{c}35.84 \\
243.19 \\
29.70\end{array}$ & $\begin{array}{c}30.58-41.09 \\
224.10-262.28 \\
25.78-33.61\end{array}$ & $\begin{array}{c}29.93 \\
108.71 \\
22.30\end{array}$ & $\begin{array}{l}2.66 \\
9.65 \\
1.98\end{array}$ \\
\hline Total negative samples & 48 & $\begin{array}{l}\mathrm{R} \\
\mathrm{G} \\
\mathrm{B}\end{array}$ & $\begin{array}{c}97.50 \\
247.92 \\
82.44 \\
\end{array}$ & $\begin{array}{c}79.91-115.10 \\
225.30-270.53 \\
67.36-97.53\end{array}$ & $\begin{array}{l}61.27 \\
78.72 \\
52.52 \\
\end{array}$ & $\begin{array}{c}8.75 \\
11.24 \\
7.50 \\
\end{array}$ \\
\hline
\end{tabular}


Fig. 1A, B shows images of the microcosm follow up and a negative image (Fig. 1C, D), and the correlation output in RGB channels. The output is an upper view of correlation peaks in color scale, the darkest colors are the lowest correlation values and the lightest colors represent the highest correlation values.
We observed a correct identification of $V$. cholerae 01 in the green channel with maximum correlation peaks, and no or low correlation peaks in the red and blue channels for positive images. For each positive image it was possible to count the number of bacteria in the green channel.

\section{Figure 1}

Images of microcosm positive and negative samples. $A$ and $B$, positive; $C$ and $D$, negative controls. Columns 2 to 4 show the correlation output in the red, green and blue channels respectively

Imágenes de muestras positivas y negativas de microcosmo. A y B, positivas; $\mathrm{C}$ y D, controles negativos. Las columnas 2 a 4 muestran la salida de correlación en los canales rojo, verde y azul respectivamente

\section{Channel}

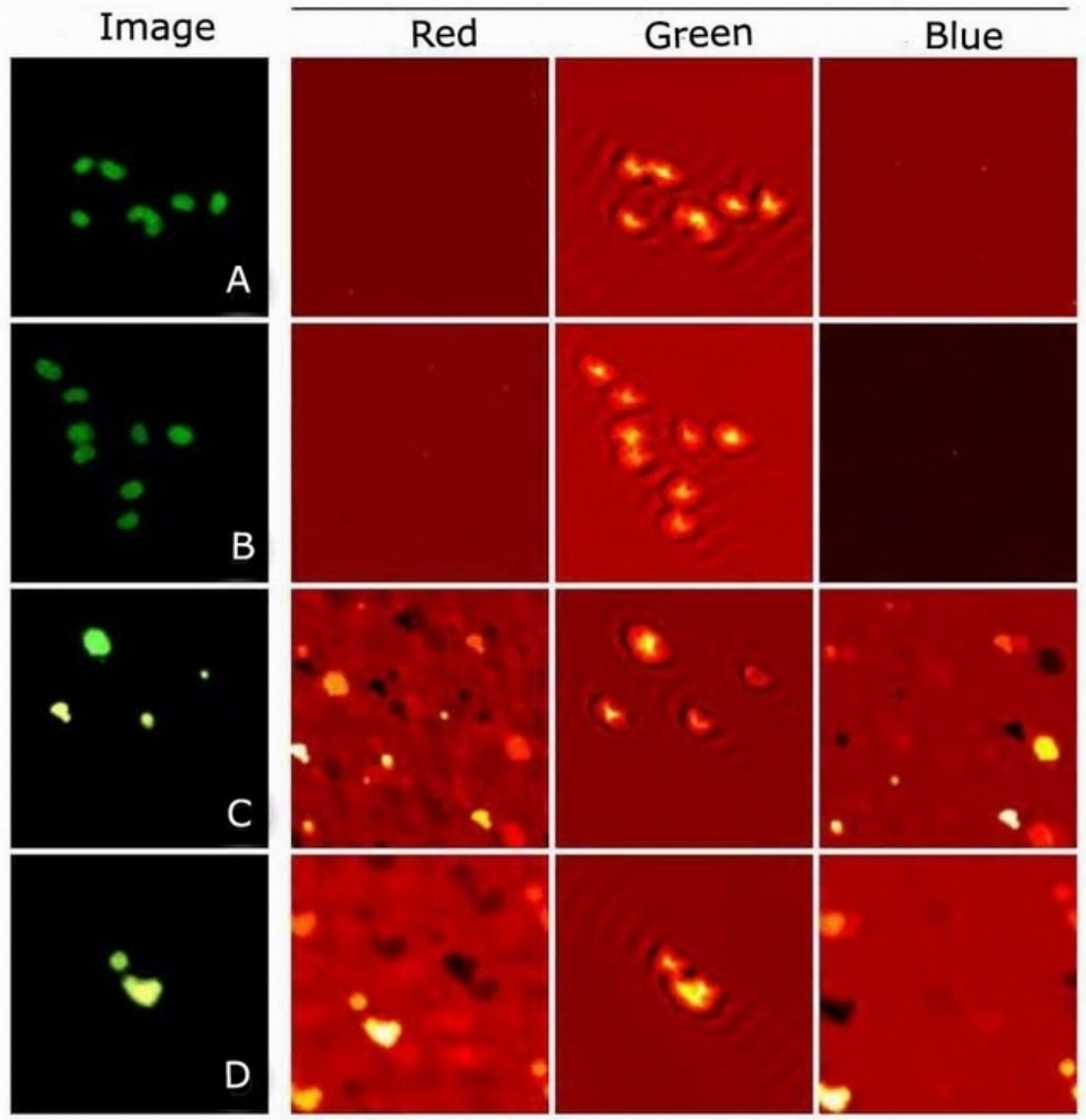


In negative images, we observed a discrimination of non- $V$. cholerae 01 particles due to the presence of maximum correlation peaks in the red and blue channels.

Based on these findings, the decision algorithm yields a positive recognition when the correlation peaks present in the green channel are low or absent in the red and blue channels. Conversely, $V$. cholerae absence is indicated when correlation peaks are present in the red and blue channels output.

It is possible to use a threshold value set at half of the highest correlation value in the green channel to avoid background noise.

The algorithm presented here is different from the one used by other authors (Millán et al. 1989, 1991, 1992, 1995) which proposed to recognize objects through the logic or arithmetic sum of results in the RGB channels. In other words, they considered a correct identification when the maximum correlation peaks appeared simultaneously in the three channels and a correct discrimination when it did not occur.

The differences between our algorithm and those proposed by other authors (Millán et al. 1989, 1991, 1992, 1995) depend on the monochromatic components of a polychromatic object in RGB channels. If any object, like fluorescent $V$. cholerae 01 is stained of green, and it exclusively has information in one channel the recognition must be done with the algorithm proposed in this work.

Thus, we cannot generalize an algorithm to be used for species identification because it depends on the analysis of the chromatic nature of the target. In fact, almost all works with color correlation systematically eliminate the blue channel output, because it has been found that this channel does not give important information.

In this work, the red channel offered more information for discrimination than the blue channel. But in some negative cases, maximum correlation peaks appear only in the blue channel. Thus, we recommend performing the correlation procedure using all three channels in order to have more efficiency in recognition.

Table 2 shows data to calculate sensitivity and specificity of digital correlation. For the first set of samples both were $100 \%$. This means that in all positive samples $V$. cholerae 01 was recognized (sensitivity $100 \%)$ and all negative were discriminated as $V$. cholerae 01 free (specificity 100\%).

In addition, 33 positive and 34 negative $V$. cholerae 01 images of real seawater samples were analyzed. Table 1 shows correlation results between these kinds of images and the POF. The means of absolute correlation values were higher for negative images in each channel including the green one $(P<0.01)$.

Table 2

Comparison of the results of the evaluation of laboratory and environmental samples with the digital system and with an expert

Comparación de los resultados de la evaluación de muestras ambientales y de laboratorio con el sistema digital y con un experto

\begin{tabular}{|c|c|c|c|c|c|c|c|c|}
\hline \multirow[b]{2}{*}{ Digital Method } & \multicolumn{2}{|c|}{ Microcosm samples* } & \multicolumn{2}{|c|}{ Environmental samples* } & \multicolumn{2}{|c|}{ Mesocosm samples* } & \multicolumn{2}{|c|}{ Total $^{*}$} \\
\hline & $\begin{array}{l}\text { Positive } \\
\text { samples }\end{array}$ & $\begin{array}{c}\text { Negative } \\
\text { samples }\end{array}$ & $\begin{array}{l}\text { Positive } \\
\text { samples }\end{array}$ & $\begin{array}{c}\text { Negative } \\
\text { samples }\end{array}$ & $\begin{array}{l}\text { Positive } \\
\text { samples }\end{array}$ & $\begin{array}{l}\text { Negative } \\
\text { samples }\end{array}$ & $\begin{array}{l}\text { Positive } \\
\text { samples }\end{array}$ & $\begin{array}{c}\text { Negative } \\
\text { samples }\end{array}$ \\
\hline $\begin{array}{l}\text { Positive } \\
\text { samples }\end{array}$ & 94 & 0 & 31 & 3 & 562 & 0 & 687 & 3 \\
\hline $\begin{array}{l}\text { Negative } \\
\text { samples }\end{array}$ & 0 & 115 & 1 & 31 & 51 & 546 & 52 & 692 \\
\hline
\end{tabular}

\footnotetext{
*Expert evaluation
} 
Figure 2A exemplifies positive environmental samples and their correlation with the POF in RGB channels. An efficient identification of cholera bacillus was found in spite of background noise generated by the rest of the elements in the scene. Again, maximum correlation peaks were observed in the green channel and low or absent correlation peaks in the red and blue channels.
In 12 out of 33 positive images, we had higher correlation peaks with elements other than $V$. cholerae 01 (Fig. 2B). This represents a sensitivity of 64\%. To increase this value all images were preprocessed using the Laplace transformation and a POF was used with the same preprocessing. In this case a correct identification was made in 31/34 images, representing 94\% sensitivity (Table 2). Fig. 2C shows examples of preprocessing images.

\section{Figure 2}

Images of environmental positive samples. A, Positive; B, without preprocessing; C, preprocessed. Columns 2 to 4 show the correlation output in the red, green and blue channels respectively

Imágenes positivas de muestras ambientales. A, Positiva; B, sin preprocesamiento; C, preprocesadas. Las columnas 2 a 4 muestran la salida de correlación en los canales rojo, verde y azul respectivamente

\section{Channel}

\section{Image}
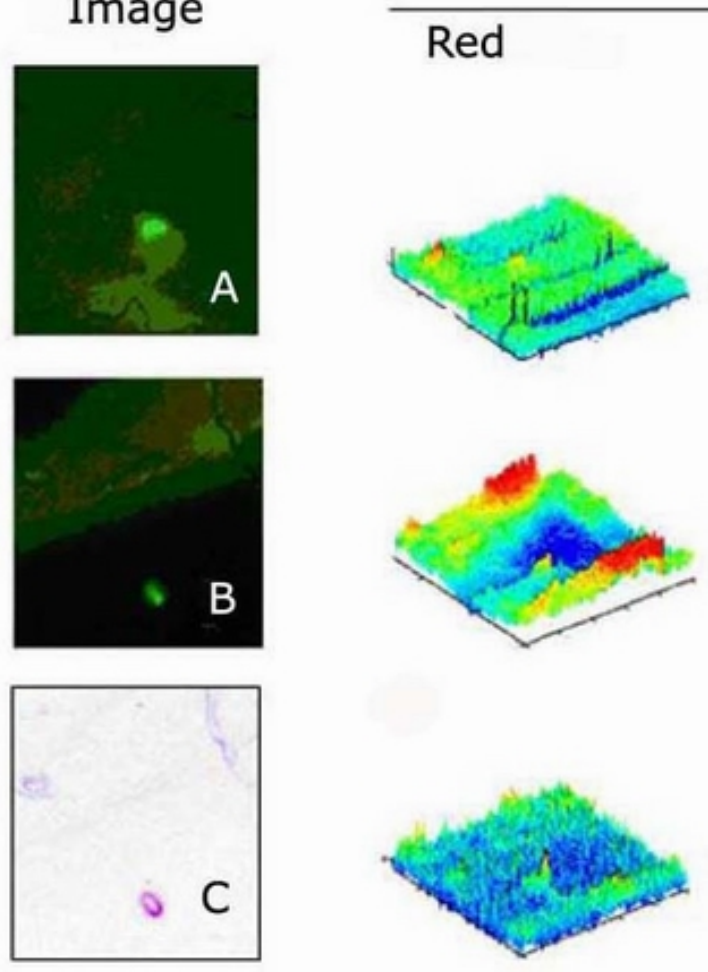
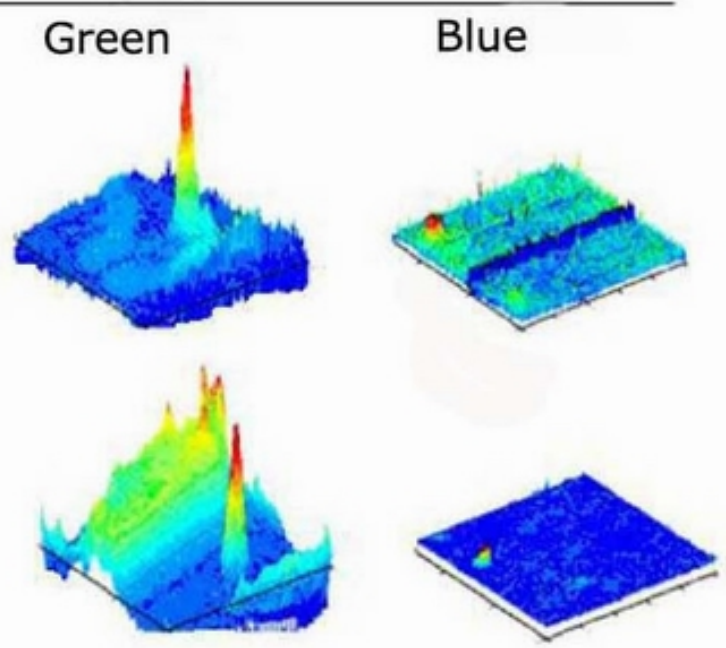

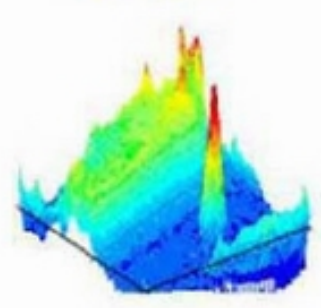

Blue
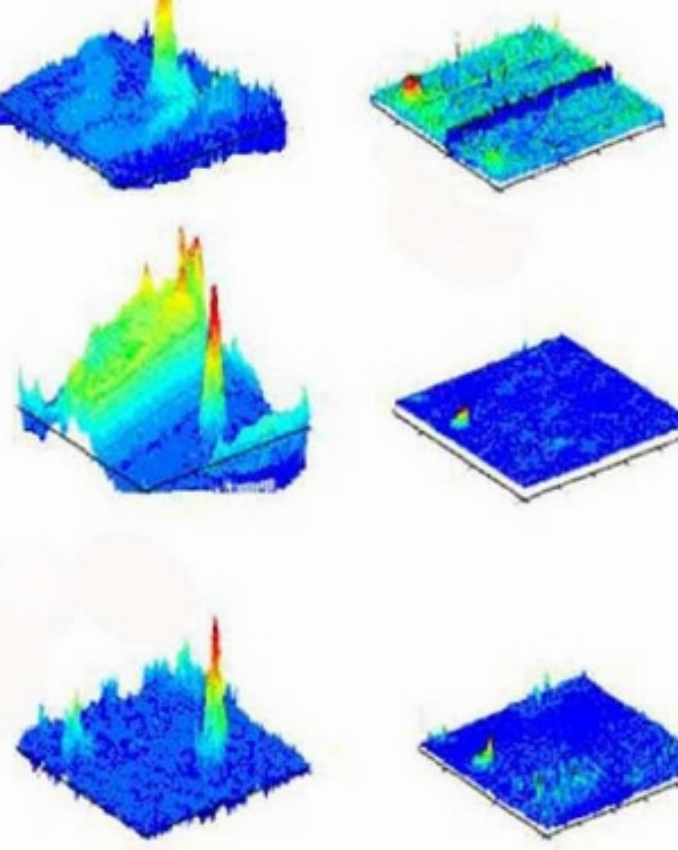

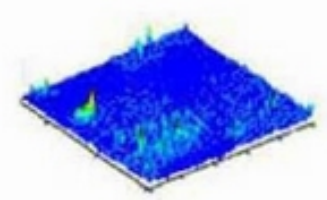


From 34 negative scenes, the system made a correct discrimination in 29 images, Specificity of $85 \%$. Four of the samples were identified as doubtful and one gave a false positive.

The reproducibility of the method is $100 \%$. Any time the identification process is repeated on the same image the same result is obtained.

In order to corroborate the capability of digital color correlation for environmental samples, a mesocosm experiment was performed to simulate a seawater coastal condition and it was inoculated with $V$. cholerae 01. Following the same procedure but using motorized microscope, we recorded 613 images of positive samples and 546 images of negative samples. After digital correlation with POFs. It was possible to recognize as positive 562 and discriminate as negatives all the samples in that group (sensitivity $91.7 \%$ and specificity of $100 \%$, Table 2 ).

We show evidence that digital color correlation systems are a useful automated tool for the identification and quantification of $V$. cholerae 01 in laboratory and environmental samples.

In $V$. cholerae, environmental monitoring is very important for the surveillance of the disease. Considering the distribution and concentration of this bacteria, it is necessary to evaluate a considerably large number of samples; it could be better an automated method $100 \%$ reproducible, highly efficient, that reduces the observer bias to 0 and making possible to quantify its error.

The color correlation system presented here was $100 \%$ effective at identifying laboratory $V$. cholerae 01 samples and up to $94 \%$ effective at identifying $V$. cholerae in environmental samples. The lower sensitivity values in environmental samples is due to the presence of many green particles besides the $V$. cholerae that produce background noise and complicate the identification. Nevertheless, the color correlation method presented here should be a useful for the rapid screening for the presence of $V$. cholerae in the environment.

Efficient identification, discrimination and quantification were possible for all microcosm samples. The 94 multichannel correlations of positive images of microcosms showed that the presence and quantity of $V$. cholerae 01 must be evaluated in the green channel output. Maximum correlation peaks in this channel reflect the presence of the $V$. cholerae and its coordinate location. High correlation peaks in the red and blue channels outputs, indicates the presence of non- $V$. cholerae 01 particles.

\section{Acknowledgments}

This project was supported by CONACyT (36075-B Procesado automático de partículas biogénicas). To Dr. Marcial Leonardo Lizarraga-Partida, Titular Researcher of Biotechnology Department, CICESE, who shared with us his laboratory and gave us the positive environmental samples, and to the Public Health Department of Medicine School at U. N. A. M. for Vibrio cholerae 01 strains.

\section{Literature cited}

Blake PA. 1994. Historical perspectives on pandemic cholerae. In: Vibrio cholerae and cholera: Molecular to global perspectives. pp. 293-295. American Society for Microbiology. Washington D.C.

Bradiqué E, Y Komiya, N Ohyama, J Tsujiuchi \& T Honda. 1987. Color image correlation. Optics Communications 61(3): 181-186.

Colwell RR \& A Huq. 1994. Environmental reservoir of Vibrio cholerae. Annals New York Academy of Sciences 740: 44-54.

Epstein PR. 1995. Emerging diseases and ecosystems instability: new threats to public health. American Journal Public Health 85: 168-172.

Ferreira C, MS Millán, MJ Yzuel \& J Campos. 1992. Experimental results in color pattern recognition by multichannel matched filtering. Optical Engineering 31(10): 2231-2238.

Hasan JAK, A Huq, ML Tamplin, RJ Siebeling \& RR Colwell. 1993. A novel kit for rapid detection of Vibrio cholerae 01. Journal of Clinical Microbiology 32(1): 249252.

Hasan JAK, D Bernstein, A Huq, L Loomis, ML Tamplin \& RR Colwell. 1994. Cholera DFA: An improved direct fluorescent monoclonal antibody staining kit for rapid detection and enumeration of Vibrio cholerae 01. FEMS Microbiology Letters 120: 143-148.

Hasan JAK, A Huq, GB Nair, S Garg, AK Mukhopadhyay, L Loomis, D Bernstein \& RR Colwell. 1995. Development and testing of monoclonal antibodybased rapid immunodiagnostic test kits for direct detection of Vibrio cholerae 0139 Synonym Bengal. Journal Clinical Microbiology 33(11): 2935-2939. 
Huq A \& RR Colwell. 1995. Vibrios in the marine and estuarine environments. Journal Marine Biotechnology 3: 60-63.

Millán MS, J Campos, C Ferreira \& MJ Yzuel. 1989. Matched filter and phase only filter performance in colour image recognition. Optics Communications 73(4): 277284.

Millán MS, MJ Yzuel, J Campos \& C Ferreira. 1991. Strategies for the colour character recognition by optical multichannel correlation. SPIE Holographic Optics III: Principles and Applications 1507: 183-193.

Millán MS, MJ Yzuel, J Campos \& C Ferreira. 1992. Different strategies in optical recognition of polychromatic images. Applied Optics 31(14): 2560-2567.

Millán MS, M Corbalán, J Romero \& MJ Yzuel. 1995. Optical pattern recognition based on color vision models. Optics Letters 20(16): 1722-1724.

Pech-Pacheco, JL \& J Alvarez-Borrego. 1998. Opticaldigital processing applied to the identification of five phytoplankton species. Marine Biology 132 (3): 357-365.

Singleton FL, TW Attwel, MS Jangi \& RR Colwell. 1982a. Effects of temperature and salinity on Vibrio cholerae growth. Applied Environmental Microbiology 44: 10471058.
Singleton FL, TW Attwel, MS Jangi \& RR Colwell. 1982b. Influence of salinity and organic nutrient concentration on survival and growth of Vibrio cholerae in aquatic microcosms. Applied Environmental Microbiology 43: 1080-1085.

Tamplin DL, AL Gauzens, A Huq, DA Sack \& RR Colwell. 1990. Attachment of Vibrio cholerae serogroup 01 to zooplankton and phytoplankton of Bangladesh waters. Applied Environmental Microbiology 56: 19771980.

Tamplin ML \& RR Colwell. 1986. Effects of microcosm salinity and organic substrate concentration on production of Vibrio cholerae enterotoxin. Applied Environmental Microbiology 52(2): 297-301.

Vander Lugt A. 1964. Signal detection by complex spatial filtering. IEEE Transaction Information Theory IT-10: 139-145.

Zavala-Hamz V \& J Alvarez-Borrego. 1997. Circular harmonic filters for the recognition of marine microorganisms. Applied Optics 36(2): 484-489. 